Environment Conservation Journal 14(3) 79-83, 2013

ISSN 0972-3099 (Print) 2278-5124 (Online)

Abstracted and Indexed

\title{
Mycological and physico-chemical study of a fish pond in Paniyala in Haridwar district of Uttarakhand
}

\author{
D.R. Khanna, Rajni Rana $\bowtie$ and Fouzia Ishaq
}

Received: 26.8.2013

Revised: 21.10.2013

Accepted: 11.11.2013

\begin{abstract}
Water is essential to life, but many people do not have access to clean and safe drinking water and many die of waterborne microbial infections. Mycological studies and physico-chemical parameters are an important criterion for evaluating the suitability of water for various purposes. In this study, we tried to assess the fungal species richness and physico-chemical status of fish pond in Paniyala in Haridwar district of Uttarakhand to predict the state of this pond. A total of four species were recorded which include Aspergillus flavus, Candida albicans, Penicillium Spp. and Fusarium Spp. Present study revealed that among fungal species, Aspergillus flavus was reported with higher in number $7.44 \pm 3.45$ (ml ${ }^{-}$ $\left.{ }^{1} \times 10^{3}\right)$ and Fusarium Spp.was recorded with minimum number of $5.15 \pm 2.06\left(\mathrm{ml}^{-1} \times 10^{3}\right)$. The total species diversity was higher in the month of April $\left(39.80 \mathrm{ml}^{1} \times 10^{3}\right.$. The water samples were also analyzed for physico-chemical parameters like temperature, $\mathrm{pH}$, conductivity, $\mathrm{DO}, \mathrm{BOD}$, Free $\mathrm{CO}_{2}$, calcium and magnesium. Higher value of temperature, $\mathrm{pH}$, $\mathrm{BOD}$, Free $\mathrm{CO}_{2}$ and lower values of dissolved oxygen concentration were recorded and the results revealed deteriorated water quality. The fungal population showed positive significant correlation with physico-chemical parameters like, temperature, $\mathrm{pH}$, biological oxygen demand, calcium and magnesium whereas negatively correlated with conductivity and dissolved oxygen.
\end{abstract}

Keywords: Aspergillus flavus, mycological, Paniyala, physico-chemical

\section{Introduction}

Water is essential to life. An adequate, safe and accessible supply must be available to all. Improving access to safe drinking-water can result in significant benefits to health. Every effort should be made to achieve a drinking water quality as safe as possible. All factors occurring in the pond, whether physical, chemical or biological, influence the pond ecosystem. The pond ecosystem is only just beginning to be understood and is of course extremely complicated and intricate. Micro organisms are the most abundant organisms in natural freshwater systems and also play a key role in ecological processes. Detailed knowledge of the diversity and function of microorganisms dwelling in freshwater habitats is an essential prerequisite for the sustainable management of freshwater resources. Microorganisms are widely distributed in nature and their abundance and diversity may be used as an indicator for the suitability of water (Okpokwasili and Akujobi, 1996).

\section{Author's Address}

Department of Zoology and Environmental Science, Gurukula

Kangri University, Haridwar

Email: drkhanna2002@gmail.com
The use of fungal species as water quality indicators can be viewed in two ways, first, the presence of such species can be taken as an indication of pollution and contamination of the water and thus as a signal to determine why such contamination is present, how serious it is and what steps can be taken to eliminate it; second, their presence can be taken as an indication of the potential danger of health risks that it posses. The higher the level of pollution, the higher the level of fungal species and greater is the risk of water-borne diseases (Pipes, 1981). A wide range of pathogenic microorganisms can be transmitted to humans via water contaminated with sewage. The overall objective of this work was to investigate the fungal and physico-chemical status of fish pond in Paniyala in Haridwar district of Uttarakhand in India.

\section{Material and methods} Physio-geographical features of Paniyala pond State : Uttarakhand District : Haridwar Town : Roorkee 
Khanna et al.

$\begin{array}{lcc}\text { Village } & : & \text { Paniyala } \\ \text { Height (from sea level) } & : & 268.0 \mathrm{~m} \\ \text { Latitude } & : & 29^{\circ} 51^{\prime} \mathrm{N} \\ \text { Longitude } & : & 77^{\circ} 53^{”} \mathrm{E} \\ \text { Length of pond } & : & 400.0 \mathrm{~m} \\ \text { Width of pond } & : & 250.0 \mathrm{~m} \\ \text { Minimum depth } & : & 0.60 \mathrm{~m} \\ \text { Maximum depth } & : & 2.80 \mathrm{~m} \\ \text { Mean depth } & : & 1.70 \mathrm{~m} \\ \text { Surface area } & : & 292,500.0 \text { square meter } \\ \text { Catchment area } & : & 292,400.0 \text { square meter }\end{array}$

\section{Sampling strategy}

For present study of the Paniyala pond, the water samples were collected monthly from four different sampling sites during March 2008 to February 2009 in morning hours. The samples were taken in borosil glass bottles of $300 \mathrm{ml}$ and plastic cans of 1.0 L from each location. The collection and analysis of water samples was done using standard methods with the help of Welch (1948), Trivedi and Goel (1986), APHA (1998) and Khanna and Bhutiani (2003) for physico-chemical parameters. For isolation and identification of aquatic fungi, 1 $\mathrm{ml}$ sample from selected dilutions were transferred into sterilized petri plates by opening them gently. 15-20 ml Rose Bengal media was used and slowly poured in these plates having a temperature of 45 ${ }^{\circ} \mathrm{C}$. Sample and media were mixed gently by rotating the plates. When medium solidified, plates were incubated at $27{ }^{\circ} \mathrm{C} \pm 2$ temperature for 48 hours in an inverted position. The colonies were counted after 2to 3 days by colony counter and colony forming unit (CFU/ml) was calculated.

\section{$\mathrm{CFU} / \mathrm{ml}=$ Clonies counted/ dilution factor}

\section{Results and discussion}

The results and data collected on physico-chemical parameters during the present investigation are presented in Table 1. Water physico-chemistry changes are dependent on and influenced by the regions in which it occurs, as a result of different climate, geomorphology, geology and soils and biotic composition (Dallas and Day, 2004). Water physical-chemical changes influence aquatic community changes. Temperature can be described as a condition that is responsible for the transfer of heat within bodies. Temperature contributes to the solubility of $\mathrm{H}_{2}, \mathrm{~N}_{2}, \mathrm{CO}_{2}$ and $\mathrm{O}_{2}$ which play vital roles in aquatic ecosystems (Gillooly et al. 2002). In the present study temperature was reported maximum of $29.70{ }^{\circ} \mathrm{C}$ in the month of May and minimum of $17.93{ }^{\circ} \mathrm{C}$ in the month of December. Conductivity also called salinity is the parameter that is used to estimate concentrations of total dissolved solids (TDS) (DWAF, 1996). Dissolved salts or ions carry an electric charge.During present study conductivity was recorded with the highest of $82.25 \mu \mathrm{mho} / \mathrm{cm}^{2}$ in the month of November and the lowest of $37.50 \mu \mathrm{mho} / \mathrm{cm}^{2}$ in the month of May. The conductivity was found negatively correlated with temperature $(r=-0.791, p<0.01)$ (Table 2). The $\mathrm{pH}$ of pond water in general showed an alkaline tendency during all the months (Table 1). The maximum $\mathrm{pH}$ noticed in the study period was 8.37 in the month of April and the minimum $\mathrm{pH}$ noticed was 7.73 in the month of August. $\mathrm{pH}$ showed a negative correlation with temperature and conductivity. Oxygen occurs naturally in the atmosphere as gas and is also produced via photosynthesis. Oxygen is not readily soluble in water, and its solubility relies on temperature, salinity and atmospheric pressure (DWAF, 1996). Dissolved oxygen (DO) is critical for sustenance of aquatic life in order for aerobic species to be able to survive and carry out their ecological functions. Lack of DO can lead to anaerobic decomposition of organic matter, resulting in unpleasant odour that is indicative of formation of hydrogen sulphide and ammonium (Schindler, 1981).The concentration of DO during present study was recorded with the maximum of $8.90 \mathrm{mg} / \mathrm{l}$ in the month of December and minimum of $4.98 \mathrm{mg} / \mathrm{l}$ in the month of May. D.O was found negatively correlated with temperature $(\mathrm{r}=-0.953, \mathrm{p}<0.01)$ and positively correlated with conductivity and $\mathrm{pH}$ (table 2). BOD is the measure of degradable organic matter present in a water sample and is defined as the amount of oxygen required by microorganisms in stabilizing biologically degradable organic matter under aerobic conditions. BOD of the pond water during the study varied from minimum of $2.93 \mathrm{mg} / \mathrm{l}$ in the month of December to the maximum of $4.73 \mathrm{mg} / \mathrm{l}$ in the month of June. BOD was found significantly positively correlated with temperature $(r=0.838, \mathrm{p}<$ 0.01 ) (table 2) but negatively correlated with conductivity, $\mathrm{pH}$ and D.O. Calcium is one of the most abundant substances in natural water. 
Table 1: Average values of physico-chemical parameters of Paniyala fish pond from 2008-2009

\begin{tabular}{|c|c|c|c|c|c|c|c|c|}
\hline Month & Temperature & Conductivity & pH & D.O & BOD & Free $\mathrm{CO}_{2}$ & Calcium & Magnesium \\
\hline March & 26.35 & 42.50 & 8.32 & 6.63 & 3.73 & 2.81 & 29.55 & 16.79 \\
\hline April & 28.13 & 38.50 & 8.37 & 5.55 & 4.05 & 3.63 & 32.98 & 18.05 \\
\hline May & 29.70 & 37.50 & 8.34 & 4.98 & 4.28 & 3.22 & 36.10 & 24.98 \\
\hline June & 29.05 & 39.25 & 8.28 & 5.13 & 4.73 & 2.58 & 37.25 & 26.05 \\
\hline July & 28.98 & 41.50 & 7.84 & 5.50 & 4.50 & 1.91 & 29.35 & 12.30 \\
\hline August & 27.13 & 58.00 & 7.73 & 5.70 & 4.18 & 2.73 & 27.43 & 11.93 \\
\hline September & 29.13 & 52.00 & 8.12 & 6.43 & 3.85 & 1.37 & 27.88 & 12.03 \\
\hline October & 27.48 & 75.25 & 8.27 & 6.48 & 3.28 & 1.21 & 28.78 & 12.73 \\
\hline November & 20.78 & 82.25 & 8.24 & 8.43 & 3.13 & 1.36 & 28.33 & 11.08 \\
\hline December & 17.93 & 79.33 & 8.23 & 8.90 & 2.93 & 2.21 & 27.50 & 14.25 \\
\hline January & 20.05 & 73.25 & 8.20 & 8.25 & 3.18 & 2.91 & 27.43 & 14.53 \\
\hline February & 23.23 & 55.00 & 8.22 & 7.70 & 3.45 & 2.78 & 26.90 & 16.28 \\
\hline Avg. \pm S.D & $\begin{array}{l}25.66 \\
\pm 4.09\end{array}$ & $\begin{array}{c}56.19 \\
\pm 17.17\end{array}$ & $\begin{array}{c}8.18 \\
\pm 0.20\end{array}$ & $\begin{array}{c}6.64 \\
\pm 0.37\end{array}$ & $\begin{array}{c}3.77 \\
\pm 0.59\end{array}$ & $\begin{array}{c}2.39 \\
\pm 0.78\end{array}$ & $\begin{array}{l}29.95 \\
\pm 3.53\end{array}$ & $\begin{array}{l}15.91 \\
\pm 4.98\end{array}$ \\
\hline
\end{tabular}

Table 2: Pearson correlation coefficient between physico-chemical parameters of Paniyala fish pond

\begin{tabular}{|l|c|c|c|c|c|c|c|c|}
\hline & Temperature & Conductivity & $p H$ & $D O$ & $B O D$ & Free $\mathrm{CO}_{2}$ & Calcium & Magnesium \\
\hline Temperature & 1 & & & & & & & \\
\hline Conductivity & $-0.791^{*}$ & 1 & & & & & & \\
\hline$p H$ & -0.131 & -0.021 & 1 & & & & & \\
\hline $\mathrm{DO}$ & $-0.953^{*}$ & $0.829^{*}$ & 0.161 & 1 & & & & \\
\hline BOD & $0.838^{*}$ & $-0.864^{*}$ & -0.283 & $-0.919^{*}$ & 1 & & & \\
\hline Free CO 2 & 0.088 & -0.538 & 0.215 & -0.288 & 0.317 & 1 & & \\
\hline Calcium & 0.568 & -0.651 & 0.416 & -0.689 & 0.681 & 0.415 & & 1 \\
\hline Magnesium & 0.371 & -0.614 & 0.515 & -0.505 & 0.532 & 0.589 & $0.900^{*}$ & 1 \\
\hline
\end{tabular}

The quantity of $\mathrm{Ca}$ in natural water generally varies from 10-100 mgL-1 depending on the type of rocks (Trivedy and Goel, 1986). Magnesium occurs in all kinds of natural water with calcium, but the concentration remains generally lower than that of calcium. During the present study the concentration of calcium and magnesium ranged from the minimum of $26.90 \mathrm{mg} / \mathrm{l}$ in the month of February and $11.08 \mathrm{mg} / \mathrm{l}$ in the November to the maximum of $37.25 \mathrm{mg} / \mathrm{l}$ and $26.05 \mathrm{mg} / \mathrm{l}$ in the June. Calcium and magnesium showed significant positive correlation with temperature, $\mathrm{BOD}$ and free $\mathrm{CO}_{2}$ but negatively correlated with conductivity and dissolved oxygen.

\section{Aquatic fungi of Paniyala pond}

Aquatic fungi are found wherever non living organic matter occurs, although some species are pathogenic and others are parasitic, unpolluted pond water has relatively large number of species representing the aquatic fungi (species possessing flagellated zoospore and gametes) aquatic hypomycetes and soil fungi (Khanna and Chugh, 2004). The results of fungi are presented in table 3 and 4. During the study period a total of four species of fungi was identified which include Aspergillus flavus, Candida albicans, Penicillium Spp. and Fusarium Spp. Present study revealed that among fungal species, Aspergillus flavus was reported with higher in number $7.44 \pm 3.45 \mathrm{ml}^{-}$ ${ }^{1} \mathrm{x} 10^{3}$ ) and Fusarium Spp.was recorded with minimum number of $5.15 \pm 2.06\left(\mathrm{ml}^{-1} \times 10^{3}\right)$. The total species diversity was higher in the month of April (39.80 $\mathrm{ml}^{-1} \times 10^{3}$. Aspergillus flavus reported maximum of $12.80 \mathrm{ml}^{-1} \times 10^{3}$ in the month of October and minimum of $2 \mathrm{ml}^{1} \times 10^{3}$ in the month of December. Aspergillus flavus was reported to be dominant during the whole study period. Candida albicans was found highest of $11.50 \mathrm{ml}^{-1} \times 10^{3}$ in the month of March and April and minimum of 2.50 $\mathrm{ml}^{-1} \times 10^{3}$ in the month of July. 
Khanna et al.

Table 3: Average values of fungal species identified from Paniyala fish pond from 2008-2009

\begin{tabular}{|c|c|c|c|c|c|}
\hline Month & Aspergillus flavus & Candida albicans & Penicillium Spp. & Fusarium Spp. & $\begin{array}{c}\text { Total } \\
\left(\mathrm{ml}^{-1} \times 10^{3}\right)\end{array}$ \\
\hline March & 10.00 & 11.50 & 8.00 & 7.00 & 36.50 \\
\hline April & 10.30 & 11.50 & 10.30 & 7.80 & 39.80 \\
\hline May & 7.75 & 10.00 & 7.25 & 5.80 & 30.80 \\
\hline June & 11.80 & 4.75 & 9.75 & 2.30 & 28.50 \\
\hline July & 4.75 & 2.50 & 6.50 & 6.80 & 20.50 \\
\hline August & 6.00 & 5.50 & 2.25 & 2.00 & 15.80 \\
\hline September & 8.50 & 7.50 & 5.75 & 5.80 & 27.50 \\
\hline October & 12.80 & 5.50 & 9.75 & 7.50 & 35.50 \\
\hline November & 2.75 & 4.75 & 9.50 & 6.30 & 23.30 \\
\hline December & 2.00 & 7.00 & 4.25 & 3.00 & 16.30 \\
\hline January & 7.75 & 5.50 & 5.50 & 3.50 & 22.30 \\
\hline February & 5.00 & 4.25 & 6.75 & 4.30 & 20.30 \\
\hline Avg..\$S.D & $7.44 \pm 3.45$ & $6.69 \pm 2.91$ & $7.13 \pm 2.47$ & $5.15 \pm 2.06$ & $26.40 \pm 8.00$ \\
\hline
\end{tabular}

Table 4: Pearson correlation coefficient between physico-chemical parameters and fungal species of Paniyala fish pond

\begin{tabular}{|l|c|c|c|c|c|c|c|c|}
\hline & Temperature & Conductivity & $p H$ & $D O$ & $B O D$ & Free $\mathrm{CO}_{2}$ & Calcium & Magnesium \\
\hline $\begin{array}{l}\text { Aspergillus } \\
\text { flavus }\end{array}$ & 0.621 & -0.415 & 0.363 & -0.573 & 0.365 & 0.138 & 0.491 & 0.424 \\
\hline $\begin{array}{l}\text { Candida } \\
\text { albicans }\end{array}$ & 0.203 & -0.377 & 0.553 & -0.210 & 0.029 & 0.515 & 0.326 & 0.344 \\
\hline $\begin{array}{l}\text { Penicillium } \\
\text { Spp. }\end{array}$ & 0.263 & -0.194 & 0.685 & -0.208 & 0.097 & -0.050 & 0.520 & 0.364 \\
\hline $\begin{array}{l}\text { Fusarium } \\
\text { Spp. }\end{array}$ & 0.328 & -0.181 & 0.335 & -0.176 & -0.045 & -0.181 & 0.043 & -0.169 \\
\hline
\end{tabular}

Significant at $p<0.05$

The average count of Candida albicans was $6.69 \pm 2.91 \mathrm{ml}^{-1} \times 10^{3}$. Penicillium Spp. was found with the maximum of $10.30 \mathrm{ml}^{-1} \times 10^{3}$ in the month of April and minimum of $2.25 \mathrm{ml}^{-1} \times 10^{3}$ in the month of August. Fusarium Spp. was ranged from the lowest of $2.00 \mathrm{ml}^{-1} \times 10^{3}$ in the month of August to the highest of $7.80 \mathrm{ml}^{-1} \times 10^{3}$ in the month of April. The fungal species were positively correlated with temperature, $\mathrm{pH}$, BOD, calcium and magnesium and negatively correlated with conductivity and D.O.

\section{Conclusion}

The present study of Paniyala state fish pond indicates low dissolved oxygen concentration, high temperature and high BOD indicating poor water quality. The pond water parameters have crossed the permissible desirable limits and do not support rich biodiversity. The fungal species identified indicated polluted and contaminated pond ecosystem and the species were pathogenic and harmful for public health. Proper management and conservation practices are the need of this fish pond to remain sustainable in addition to the wealth of the state.

\section{References}

APHA 1998. Standard methodS for the Examination of water and waste water. $18^{\text {th }}$ edition American Public Health Association, Washington. DC.

Dallas H.F. and Day J.A. 2004. The effect of water quality variables on aquatic ecosystems: a review. Report No. TT 224/04. Water Research Commission. Pretoria, South Africa.

DWAF - (Department of Water Affairs and Forestry) 1996a. South African water quality guidelines. Volume 1: Domestic use. Department of Water Affairs and Forestry. Pretoria, South Africa. 


\section{Mycological and physico-chemical study}

Gillooly J.F., Charnov E.L., West G.B., Savage V.M. and Brown J.H. 2002. Effects of size and temperature on developmental time. Nature ,417:70-73.

Khanna, D. R. and Chugh, T. 2004. Microbial Ecology: A study of River Ganga, Discovery publishing house, New Delhi. 1-277.

Khanna, D.R. and Bhutiani, R. 2003.Limnological characteristic of the river Ganga at Haridwar (Uttaranchal), U.P.J.Zool., Vol. 23(3): 179-183.

Okpokwasili, G.C.and Akujobi, T.C. 1996. Bacteriological indicators of tropical water quality. Environ. Tax. Water Qual. Int. J.,11: 77-81.
Pipes,W.O. 1981. Bacterial indicators of pollution. CRC Press Inc., Boca Raton, FL, p. 242.

Schindler D.W. 1981. Interrelationships between the cycles of elements in freshwater ecosystems: some perspectives of the major biogeochemical cycles. In: Perspectives of the major biogeochemical cycles. Likens G.E. (ed). New York, USA, Chapter 7, pp 113-123.

Trivedy, R. K. and P. K. Goel 1986. Chemical and biological methods for water pollution studies. Environmental Publications. Karad, 1- 250.

Welch, P.S. 1948.Limnological Methods, the Blakiston. Co. Philadelphia, 1-381. 